\title{
SIMILARITIES AND DIFFERENCES BETWEEN ETHICAL CODES OF CONDUCT OF AICPA AND IFAC
}

\author{
AL-HASAN AL-AIDAROS \\ KAMIL MD. IDRIS \\ FARIDAHWATI MOHD. SHAMSUDIN \\ College of Business \\ Universiti Utara Malaysia
}

\begin{abstract}
An accountants' ethical code of conduct represents the moral values, principles and rules that accountants should have. The ethical codes of conduct of AICPA and IFAC are the two main codes most countries adopt to guide their members on how to deal with accounting information from the ethical perspective. While the AICPA ethical code of conduct was developed specifically for the USA, the IFAC ethical code of conduct was developed by taking into account the different practices of ethical code of conduct in various countries. The main purpose of this paper is to present an overview of the similarities and differences of these two codes. The comparison of the two documents is made on the following issues: establishment, structure and approach of the codes, the public interest principle, and the independence principle. The comparative analysis shows that the AICPA and IFAC codes are more similar than different even though some differences are noticeably important.
\end{abstract}

Keywords: Ethical code of conduct, Accountants, AICPA, IFAC.

\section{Introduction}

The collapse of several companies such as Enron and WorldCom showed the importance of ethical values and principles of professional accountants as these scandals have undoubtedly tarnished the reputation of the accounting profession and damaged public confidence in the accounting profession (AICPA, 2014, IFAC, 2014). Those scandals opened a debate on the importance of ethics among professional accountants. To restore public confidence, both the American Institute of Certified Public Accountants (AICPA) 
and the International Federation of Accountants (IFAC) are taking comprehensive steps to improve the image of the accounting profession and their members by encouraging them to adhere to ethical values and principles in their dealings with the public/ customers as specified in their documents.

Ethical values and code of conduct play an important role in the market economy (Garrison \& Noreen, 1997), as without which the economy will hold back considerably. In the case of professional accountants, who have to present accounting information accurately to the public for its final consumption, ethics are of paramount importance in the course of fulfilling their duties and responsibilities. Failure to accurately establish accounting information will result in huge losses and eventually the collapse of the market. Due to the significance of ethics in this line of profession, accounting bodies such as AICPA and IFAC have developed ethical codes of conduct for accountants to guide them on how to deal with accounting information. In fact, these bodies require their professional accountants to pass an ethics exam after completing their technical exam prior to their certification to practice (AICPA, 2014).

There are many accounting organizations or associations established across the world that primarily aim to guide the behaviors of their members. They include, among others, the American Institute of Certified Public Accountants (AICPA) and the Institute of Management Accountants (IMA) in the US, the Institute of Certified Accountants of Ontario (ICAO) and the Society of Management Accountants of Canada (SMAC) in Canada, the Institute of Chartered Accountants in England and Wales (ICAEW) in the UK, the International Federation of Accountants (IFAC), the Saudi Organization for Certified Public Accountants (SOCPA) in Saudi Arabia, and the Jordan Institute for Certified Public Accountants (JICPA) in Jordan. However, most of the accounting organizations and institutions around the world are adopting the AICPA code or the IFAC's (Mohammed, 2012).

Because of the importance of the codes of AICPA and IFAC, this paper seeks to compare and contrast the ethical code of conduct developed by AICPA and IFAC in terms of the code's structure and approach, and the principles and rules. In particular, two principles are considered, i.e. the principle of public interest and independence. Toward this end, this paper is structured as follows: first, a conceptualization of the ethical code of conduct is offered, followed by a brief introduction of AICPA and IFAC and the historical development of 
their ethical codes. Then, a comparison of the codes' structure and approach is presented. Next, discussions on how AICPA and IFAC are different or similar in explaining the principles of public interest and independence are offered. The paper then shows examples of countries that have adopted the AICPA or IFAC code. Finally, brief remarks are presented to conclude the paper.

\section{Ethical Code of Conduct}

An ethical code of conduct can be understood in different ways. It can be seen as a social agreement between the public and the accountants. The accountants' ethical code of conduct is established to positively influence the users of accounting information such as investors, employees, lenders, suppliers, customers, the government, and management (Payne \& Landry, 2005). Therefore, in this perspective, accountants have a responsibility to perform their duties with the highest level of integrity and objectivity (Bay, 1997). Alternatively, the ethical code of conduct is a means for the accounting profession to regulate its own members and thus the code is viewed as the accountants' way of self-protection (Parker, 1994). In addition, the ethical code of conduct is seen as a required component of the accountants' job (Bay, 1997). Finally, the code is viewed as an accountants' attempt, on their side, to offer guiding principles to assist them in formulating correct choices in complex circumstances (Brecht, 1991).

Specifically in the accounting profession, the ethical code of conduct is designed as guidelines of the behavior expected from accountants in order to protect their interests and the stakeholders'. Moreover, the code is developed to make sure that the services provided will be of good quality and the reputation of the accountants' job will not be tarnished (Brown et al., 2007). In other words, the guidelines serve to protect some aspects of a fiduciary relationship between the accountants and their clients. This requires the accountants to serve their clients diligently and effectively based on the ethical principles of the ethical code of conduct.

In general, an ethical code of conduct, in any profession, characterizes the principles and rules that direct the actions of the people in that profession (Delorme, Sinkhan, \& French, 2001). Thus, it is very important that organizations in society have ethical codes of conduct (Payne \& Landry, 2005). Rezaee, Elmore and Szendi (2001), 
and Wotruba, Chonko and Loe (2001) explain that ethical codes of conduct could help managers achieve five objectives: (a) improve their corporate moral values, (b) communicate and monitor their moral expectations to employees, (c) represent their obligation to moral values, (d) provide legality for their actions, and (e) help everyone in the company to resolve ethical problems.

The accounting profession has developed multiple ethical codes of conduct that set the rules for professional accountants' behavior that require more than simply adhering to the letter of the law. These codes are the equivalent of a binding organizational moral law. Consequently, these codes determine what is ethically required of professional accountants. Duska and Duska (2003) spelled out six ways that accountants' ethical code of conduct can be valuable: (a) it can motivate through using peer pressure, by holding up a generally recognized set of ethical expectations that must be considered in decision-making, (b) it can provide more stable permanent guides to right or wrong than do human personalities, (c) it can provide guidance, especially in ambiguous situations, (d) it is not only an ethical guidance for accountants, the code can also control the autocratic power of employers, (e) it can help specify the social responsibilities of the business itself, and (f) codes are clearly in the interest of the business itself, for if businesses do not police themselves ethically, others will do it for them.

\section{AICPA and IFAC: Similarities and Differences}

The first and most major ethical code of conduct for the accounting profession is the one that was established and adopted by the American Institute of Certified Public Accountants (AICPA) (Aboahmeed, 2006; Brown, 1999; Brown, Stock \& Wikder 2007; Duska et al., 2003; Mele, 2005; SOCPA, 2009; Venezia, 2005).

Historically, AICPA was founded in 1887 in the United States of America and it adopted its first code in 1893. That code addressed the issue of indiscriminate solicitation, which was considered unethical for accountants (AICPA, 2014; Brown, 1992). In 1907, a "Professional Ethics" section was added to the code. Although AICPA made the effort to develop and maintain professional ethics, it was not capable of enforcing the rules because AICPA was not recognized by any government sector (AICPA, 2014; Brown, 1992). In 1916, AICPA 
was reorganized by the American government as the accounting profession for accountants in the US. In 1917, AICPA added eight rules of conduct to the code to protect the public (AICPA, 2014; Brown, 1992). In 1947, the code included 16 rules of conduct: 10 rules were to promote public confidence and six rules to maintain orderly relationships among members of AICPA (AICPA, 2014; Brown, 1992). In 1967, AICPA appointed a special committee to review the code based on the published codes of accounting societies throughout the world as well as the ethical rules of major professions practising in the US. The committee proposed a new code which consisted of two sections: principles and rules. Since then, the code has consisted of these two main sections (AICPA, 2014; Brown, 1992).

On the other side, the International Federation of Accountants (IFAC) was founded in 1977 in Germany. IFAC established an ethical code of conduct for professional accountants that can be used globally. The IFAC ethical code of conduct was divided into two main parts: principles and rules. The principles included: (a) integrity, (b) objectivity, (c) professional competence and due care, (d) confidentiality, (e) professional behavior and (f) technical standards. The rules, on the other hand, explained the principles partly by highlighting specific behaviors that professional accountants must follow. As presented in Table 1, there were two types of rules: (a) rules in public practice such as rules that explain how to deal with audit fees and other types of remuneration and other rules that clarify how to deal with gifts and hospitality, and (b) rules in business such as rules that give explanation about how to prepare and report financial information and other rules that clarify how to deal with any potential conflicts.

Generally, the IFAC ethical code of conduct provides specific guidance to issues of independence and public interest as they are the main responsibilities of accountants. This is because these two principles are commonly accepted in most countries and societies; and these two principles are the most important objectives that the code should achieve (Brooks \& Labelle, 2006). But, the IFAC ethical code of conduct was not designed for any specific country because each country is supposed to develop its own ethical code of conduct that is consistent with the country's own rules and regulations (Brown et al., 2007; IFAC, 2014). However, if any accounting organization in any country wants to be a member of IFAC, then it must follow the ethical code of conduct of IFAC (IFAC, 2014). 
An ethical code of conduct for professional accountants is commonly divided into two parts: principles and rules. While the principles are the broader ethical values that accountants should follow, the rules explain in detail how the principles should be followed. These principles describe professional responsibilities, public interest, integrity, objectivity and independence, due care, and scope and nature of services (AICPA, 2014; Brown, Stocks \& Wilder, 2007). Table 1 shows the principles and rules, as spelled out by AICPA and IFAC as well as some other accounting organizations from several countries.

\section{Code Structure}

Both codes highlight many of the same topical areas (Allen, 2010), though some differences exist. For example, while the AICPA code explains how professional accountants in public practice may build and name their accounting practices, and describes several wrong acts that violate the code (AICPA, 2014), the IFAC's does not (Allen, 2010). Another example of similarities is both codes deal with areas such as responsibility, protecting the public interest, independence, due care, and integrity (AICPA, 2014; IFAC, 2014). As for the principles, both codes underlie almost the same principles with one main exception (Allen, 2010). The IFAC code addresses confidentiality and marketing in more detail under the principle of professional behavior which are applicable to all professionals, whereas the AICPA code incorporates these values as part of the rules which are applicable to professional accountants in public practice (AICPA, 2014; IFAC, 2014). The requirements of the IFAC code for professional accountants in business are much like those found in the AICPA code though specific IFAC rules, i.e. inducements, and acting with sufficient expertise, are more inclusive than the AICPA's (Allen, 2010). In contrast, as for the differences, the IFAC code consists of three parts, i.e. A, B, and C. While part A applies to all professional accountants and part B applies only to persons in public accounting, part $C$ applies to persons in business which means everyone who is not in public practice. On the other side, AICPA does not divide its principles and rules in that style (AICPA, 2014; IFAC, 2014).

\section{Code Approach}

The codes take somewhat different approaches. The IFAC code adopts the conceptual framework approach which is often referred to as a 'principles-based' code while others consider the AICPA code 
to be more a 'rules based' (Allen, 2010). Whilst the principles-based code (i.e. the IFAC approach) is used to evaluate ethical conduct throughout its code, the rules-based code (i.e. AICPA approach) requires professional accountants to use the principles-based approach only if the rules do not address their situation (AICPA, 2014; IFAC, 2014). As for the principles-based approach, professional accountants should comply with the fundamental principles of the IFAC code and apply this approach to determine their compliance with the fundamental principles at any time they know that a situation or associations may compromise their compliance (AICPA, 2014). The IFAC approach describes how the conceptual framework conducts in specific situations such as: how providing non-assurance services (i.e. evaluations) to an audit client may threaten an accounting firm's independence (IFAC, 2014). Another example of the situation, where the IFAC approach applies, is how receiving gifts or other incentives from a manager may threaten the objectivity of a professional accountant (IFAC, 2014). In contrast, and as mentioned before, the professional accountants who apply the AICPA approach also have the option of applying the IFAC approach when other rules in the code do not address their situations (AICPA, 2014).

Table 1

Summary of Several Ethical Codes of Conduct

\begin{tabular}{|c|c|c|c|c|c|}
\hline \multirow{2}{*}{ No } & \multirow{2}{*}{ Organization } & \multicolumn{3}{|c|}{ Contents of ethical code of conduct } & \multirow{2}{*}{ Remarks } \\
\hline & & Principles & & Rules & \\
\hline 1 & $\begin{array}{l}\text { The American } \\
\text { Institute of } \\
\text { Certified } \\
\text { Public } \\
\text { Accountants } \\
\text { (AICPA) }\end{array}$ & $\begin{array}{l}\text { (1)Professional } \\
\text { responsibilities } \\
\text { (2) Public interest } \\
\text { (3) Integrity } \\
\text { (4) Objectivity } \\
\text { and } \\
\text { independence } \\
\text { (5) Due care } \\
\text { (6) Scope and } \\
\text { nature of services }\end{array}$ & $\begin{array}{l}\text { (1) } \\
(2) \\
(3) \\
(4) \\
\text { (5) } \\
(6) \\
(7) \\
\text { (8) } \\
\text { (9) } \\
\text { (10) }\end{array}$ & $\begin{array}{l}\text { Independence } \\
\text { Integrity } \\
\text { Objectivity } \\
\text { Compliance with } \\
\text { standards } \\
\text { General standards } \\
\text { Accounting standards } \\
\text { Responsibility } \\
\text { to clients } \\
\text { (confidentiality) } \\
\text { Responsibility to } \\
\text { clients (contingent } \\
\text { fees) } \\
\text { Responsibility to } \\
\text { colleagues } \\
\text { Other responsibilities } \\
\text { (discreditable acts) }\end{array}$ & \\
\hline
\end{tabular}

(continued) 


\begin{tabular}{|c|c|c|c|c|}
\hline \multirow{2}{*}{ No } & \multirow{2}{*}{ Organization } & \multicolumn{2}{|c|}{ Contents of ethical code of conduct } & \multirow{2}{*}{ Remarks } \\
\hline & & Principles & Rules & \\
\hline & & & $\begin{array}{l}\text { (11) Other responsibilities } \\
\text { (advertising and } \\
\text { solicitation) } \\
\text { (12) Other responsibilities } \\
\text { (commission and } \\
\text { referral fees) } \\
\text { (13) Other responsibilities } \\
\text { (names and forms of } \\
\text { organization) } \\
\text { (14) Conflict of interest }\end{array}$ & \\
\hline
\end{tabular}
2 International
(1) Professional
Rules in public practice:
Federation of
behavior
(1) Professional
Accountants
(2) Confidentiality
(IFAC)
(3) Integrity appointment
(4) Objectivity
(2) Conflicts of interest
(5) Professional competence and due care and
(6) Technical
(3) Second opinions
(4) Fees and other types of remuneration
(5) Marketing professional services standards.
(6) Gifts and hospitality
(7) Custody of clients assets
(8) Objectivity-all services
(9) Independence- assurance engagements Rules in business:
(1) Potential conflicts
(2) Preparation and reporting of information
(3) Acting with sufficient expertise
(4) Financial interests and
(5) Inducements

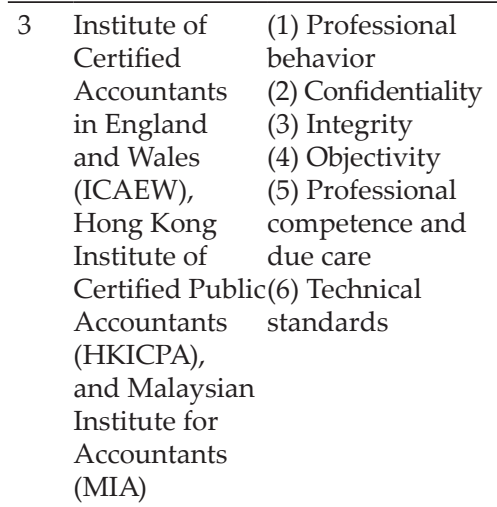

Rules in public practice:

ICAEW,

(1) Professional HKICPA, and appointment

(2) Conflicts of interest

MIA adopt

(3) Second opinions but with some

(4) Fees and other types of slight changes remuneration in wording

(5) Marketing professional services

(6) Gifts and hospitality

(7) Custody of clients assets

(8) Objectivity-all services 
IJMS 22, Special Issue 61-79 (2015)

\begin{tabular}{|c|c|c|c|c|c|}
\hline \multirow{3}{*}{ No } & \multirow{3}{*}{ Organization } & \multicolumn{3}{|c|}{ Contents of ethical code of conduct } & \multirow{3}{*}{ Remarks } \\
\hline & & \multirow[t]{2}{*}{ Principles } & \multicolumn{2}{|r|}{ Rules } & \\
\hline & & & $\begin{array}{l}(1) \\
(2) \\
(3) \\
(4) \\
(5) \\
\end{array}$ & $\begin{array}{l}\text { Independence- } \\
\text { assurance } \\
\text { engagements Rules in } \\
\text { business: } \\
\text { Potential conflicts } \\
\text { Preparation and } \\
\text { reporting of } \\
\text { information } \\
\text { Acting with sufficient } \\
\text { expertise } \\
\text { Financial interests } \\
\text { Inducements }\end{array}$ & \\
\hline 4 & $\begin{array}{l}\text { Institute of } \\
\text { Certified } \\
\text { Accountants } \\
\text { of Ontario } \\
(\mathrm{ICAO})\end{array}$ & $\begin{array}{l}\text { (1) Maintenance } \\
\text { of good } \\
\text { reputation } \\
\text { (2) } \\
\text { Confidentiality } \\
\text { (3) Integrity and } \\
\text { due care } \\
\text { (4) Objectivity } \\
\text { and } \\
\text { independence } \\
\text { (5) Professional } \\
\text { competence and } \\
\text { due care } \\
\text { (6) Compliance } \\
\text { with bylaws and } \\
\text { regulations }\end{array}$ & $\begin{array}{l}(5) \\
(6) \\
(7) \\
(8) \\
(9)\end{array}$ & $\begin{array}{l}\text { es in public practice: } \\
\text { Professional } \\
\text { appointment } \\
\text { Conflicts of interest } \\
\text { Second opinions } \\
\text { Fees and other types } \\
\text { of remuneration } \\
\text { Marketing } \\
\text { professional services } \\
\text { Gifts and hospitality } \\
\text { Custody of clients' } \\
\text { assets } \\
\text { Objectivity-all } \\
\text { services } \\
\text { Independence- } \\
\text { assurance } \\
\text { engagements Rules in } \\
\text { business: } \\
\text { Potential conflicts } \\
\text { Preparation and } \\
\text { reporting of } \\
\text { information } \\
\text { Acting with sufficient } \\
\text { expertise } \\
\text { Financial interests } \\
\text { Inducements }\end{array}$ & $\begin{array}{l}\text { The principles } \\
\text { of the ICAO } \\
\text { code mixes } \\
\text { between AICPA } \\
\text { and IFAC with } \\
\text { an additional } \\
\text { principle, i.e. } \\
\text { "compliance } \\
\text { with bylaws and } \\
\text { regulations". But } \\
\text { ICAO adopts the } \\
\text { rules of the IFAC } \\
\text { code }\end{array}$ \\
\hline 5 & $\begin{array}{l}\text { Accounting } \\
\text { and Auditing } \\
\text { Organization } \\
\text { for Gulf } \\
\text { Countries } \\
\text { (AAOGC) }\end{array}$ & $\begin{array}{l}\text { (1)Professional } \\
\text { responsibilities } \\
\text { (2) Public interest } \\
\text { (3) Integrity } \\
\text { (4) Objectivity } \\
\text { and independence } \\
\text { (5) Due care } \\
\text { (6) Scope and } \\
\text { nature of services }\end{array}$ & $\begin{array}{l}(1) \\
(2) \\
(3) \\
(4) \\
(5) \\
(6)\end{array}$ & $\begin{array}{l}\text { Independence } \\
\text { Integrity and } \\
\text { objectivity } \\
\text { Compliance with } \\
\text { standards } \\
\text { General standards } \\
\text { Accounting principles } \\
\text { Tax and zakat services }\end{array}$ & $\begin{array}{l}\text { AAOGC adopts } \\
\text { SCOPA code. } \\
\text { SOCPA adopts } \\
\text { AICPA code and } \\
\text { other codes from } \\
\text { Arab countries, } \\
\text { i.e. Egypt and } \\
\text { Kuwait, and } \\
\text { Saudi rules }\end{array}$ \\
\hline
\end{tabular}




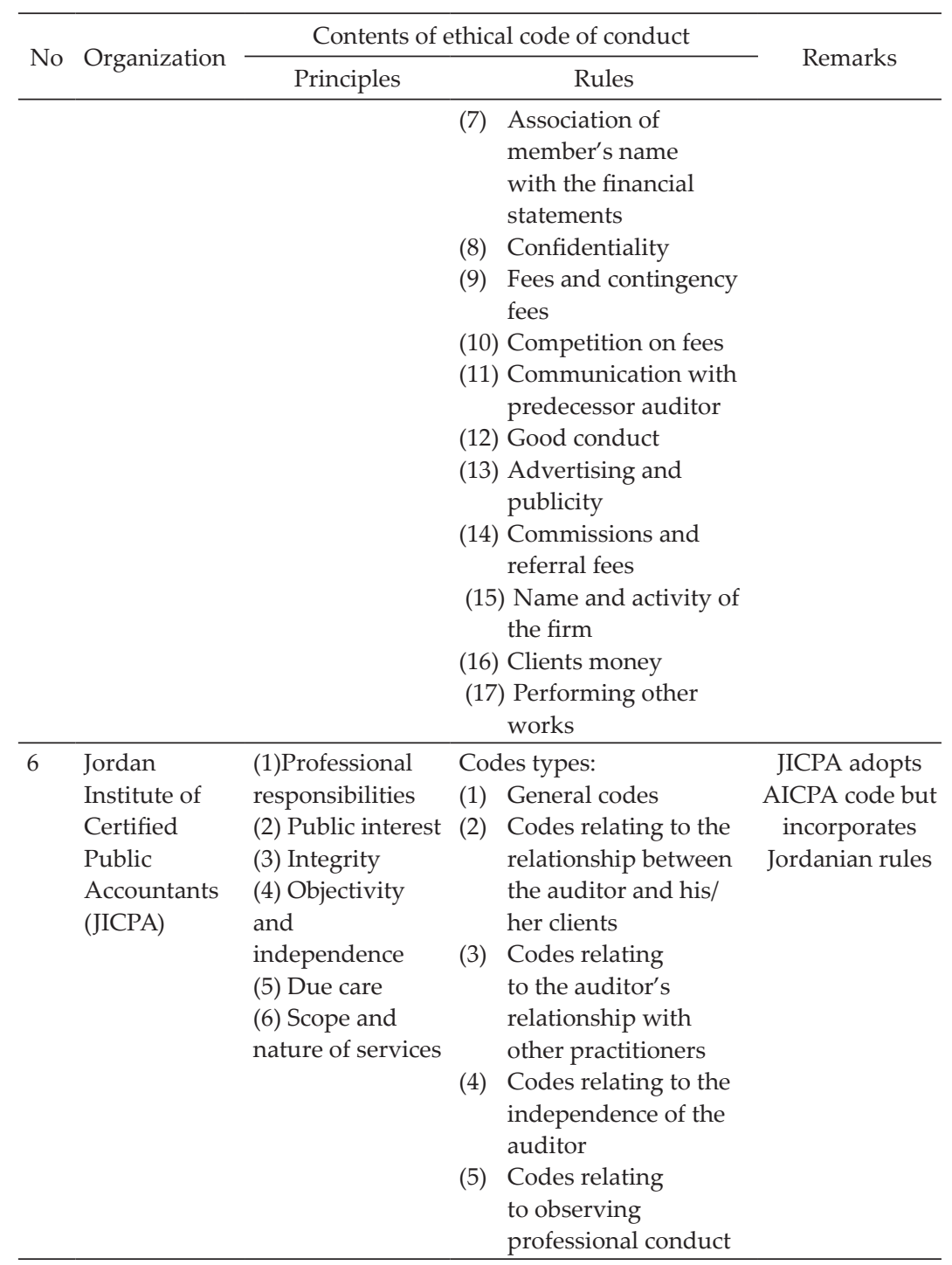

\section{Principle of Public Interest}

The principle of public interest means accountants should accept the obligation to act in a way that will serve public interest, honor public trust, and demonstrate commitment to professionalism (AICPA, 2014). The IFAC code imposes additional rules that reflect public interest in certain types of entities (IFAC, 2014). Public interest entities are 
listed entities, i.e. entities whose securities are listed on a recognized stock exchange, and entities whose auditors are required by law or regulation to comply with the same independence requirements as listed entities (IFAC, 2014). The additional rules, that are related to public interest entities, cover the following areas: (a) employment of audit team member or senior/managing partner, (b) long association of senior audit personnel with audit client, (c) bookkeeping/payroll services, (d) valuation services, (e) tax calculations, (f) internal audit services, (g) information technology system design or implementation services, (h) recruitment services, and (i) significant client fees (IFAC, 2014). The AICPA code does not include similar rules for public interest entities, which impose the IFAC code, in the previous areas (Allen, 2010). But, the AICPA code generally entails professional accountants to comply with more restrictive rules applicable to their engagements, which can bring about similar results as the rules of the IFAC public interest entities (Allen, 2010).

\section{Principle of Independence}

The principle of independence means that accountants should not make an unbiased opinion (Ahmad, 2008). The nature of the relationship between the professional accountant and his/her client is the key component for the independence principle (Goldman \& Barlev, 1974). Even though the professional accountant depends on the client for his/her source of revenue, that is fees or salary, he/she is required to be independent of the client (Windsor \& Ashkanasy, 1995). While the AICPA code does not divide its independence rules, the IFAC code splits its independence requirements into two parts. The first part consists of three issues, i.e. the prohibitions, applications to audits, and reviews of financial statements (IFAC, 2014). The second part consists of less restrictive independence rules which are relevant to all other assurance engagements. Generally, the IFAC code discusses the rules of independence in more detail than the rules of the AICPA code (Allen, 2010). For example, professional accountants concerned about the significance of their audit fee would be relevant to the AICPA conceptual framework because no AICPA independence rule exists on the subject (Allen, 2010). In view of the fact that both codes' base their independence rules on the conceptual framework approach, professional accountants should achieve a similar result applying the AICPA code as they would apply the IFAC code (AICPA, 2014). 
While minor wording differences exist, the AICPA and IFAC definitions of independence are substantially the same. Both codes, AICPA and IFAC, divide independence into two types: (a) independence of mind and (b) independence in appearance (AICPA, 2014; IFAC, 2014). As for the first type (independence of mind), while AICPA (2014) defines it as the state of mind that permits the performance of an attest service without being affected by influences that compromise professional judgment, thereby allowing an individual to act with integrity and exercise objectivity, IFAC (2014) defines it as the state of mind that permits the expression of a conclusion without being affected by influences that compromise professional judgment, thereby allowing an individual to act with integrity and exercise objectivity. And as for the other type (independence in appearance), while AICPA (2014) defines it as the avoidance of circumstances that would cause a reasonable and informed third party, having knowledge of all relevant information, including safeguards applied, to reasonably conclude that the integrity, objectivity, or professional skepticism of a firm or a member of the attest engagement team had been compromised, IFAC (2014) defines it as the avoidance of facts and circumstances that are so significant that a reasonable and informed third party would be likely to conclude, weighing all the specific facts and circumstances, that a firm's, or a member of the audit team's, integrity, objectivity or professional skepticism has been compromised.

The AICPA and IFAC independence rules incorporate the same conceptual framework approach. Both codes highlight the importance of establishing a conceptual framework that requires professional accountants to identify and evaluate the threats and then apply the safeguards as necessary to remove these threats or decrease them (AICPA, 2014; IFAC, 2014). In terms of dependence threats, the AICPA (2014) and the IFAC (2014) codes cover the same threats with minor differences in the name or description of the threats. Based on the AICPA code, the threats are (a) self-review threat, (b) advocacy threat, (c) adverse interest threat, (d) familiarity threat, (e) undue influence threat, (f) financial self-interest threat, and (g) management participation threat. In contrast, the IFAC code includes the following threats: (a) self-review threat, (b) advocacy threat, (c) familiarity threat, (d) intimidation threat, and (e) self-interest threat. The IFAC code does not include an "adverse interest threat" or "management participation threat" but the "management participation threat" is covered under its "self-review threat". The AICPA code is "undue influence threat" is referred to as the "intimidation threat" under the IFAC code. 
The safeguards of the AICPA and the IFAC frameworks are largely the same except the IFAC rules do not permit professional accountants to exclusively rely on safeguards applied by the audited company. While the AICPA (2014) code consists of three safeguards, i.e. (a) safeguards formed by the profession, legislation, or regulation, (b) safeguards applied by the attest client, and (c) safeguards executed by the company, including policies and procedures to implement professional and regulatory requirements, the IFAC (2014) code consists of two safeguards; those are safeguards formed by the profession, legislation or regulation, and safeguards which must be implemented in the work environment.

Both codes require independence during the period of the professional engagement. The AICPA code commonly emphasizes that independence will be damaged if professional accountants perform non-audit services to a potential audit client during the period covered by the financial statements (AICPA, 2014). The IFAC code requires a threats and safeguards analysis in such situations to be implemented during the period of engagement (IFAC, 2014).

\section{Adopters of AICPA and IFAC Codes of Ethics}

Some accounting organizations in countries such as Taiwan, Saudi Arabia, and Jordan adopt the principles of the AICPA ethical code of conduct. Other accounting organizations such as the Hong Kong Institute of Certified Public Accountants (HKICPA), the Malaysian institute for accountants (MIA), and the Institute of Chartered Accountants in England and Wales (ICAEW) adopt the IFAC ethical code of conduct. On the other hand, the Institute of Certified Accountants of Ontario (ICAO) adopts something that is effectively a mixture of the AICPA and the IFAC. But, the ICAO adds a new principle of "compliance with bylaws and regulations"(ICAO, 2010).

In general, Arab countries such as Jordan and the Gulf countries (Saudi Arabia, Kuwait, Qatar, Bahrain, Oman, and the United Arab Emirates) adopt the principles of the AICPA ethical code of conduct but not the rules. Some of the rules in the AICPA have been changed in these countries. For example, the Jordanian's ethical code of conduct has six principles, identical to the AICPA principles, and five groups of codes as follows: (a) general codes, (b) codes relating to the relationship between the auditor and his/her clients, (c) codes relating 
to the auditor's relationship with other practitioners, (d) codes relating to the independence of the auditor, and (e) codes relating to observing professional conduct (Abo-ahmeed, 2006). These additional codes have been added to be consistent with the Jordanian regulations and rules (Abo-ahmeed, 2006). Another example is the ethical code of conduct of the Saudi Organization for Certified Public Accountants (SOCPA) which also adopts the principles of the AICPA ethical code of conduct. But, as far as the rules of the AICPA are concerned, a few rules taken from other Arab countries such as Egypt and Kuwait and from other rules relating to zakat have been added by the SOCPA.

The Arab Gulf countries (Saudi Arabia, Kuwait, Qatar, Bahrain, Oman, and the United Arab Emirates) have their own accounting organization called the Accounting and Auditing Organization for Gulf Countries (AAOGC). AAOGC is responsible for developing the accounting profession in all Arab Gulf countries, and hence has its own ethical code of conduct. Before coming out with its ethical code of conduct, the AAOGC (2003) studied the existing ethical codes of conduct of Saudi Arabia, Kuwait, and Bahrain since the other Arab Gulf countries, i.e. Qatar, Oman, and the United Arab Emirates do not have their own ethical code of conduct. After comparing the codes of Saudi Arabia, Kuwait, and Bahrain, the AAOGC (2003) found that the ethical code of conduct of Saudi Arabia is more comprehensive one than the others. As a result, the Arab Gulf countries decided to adopt the Saudi ethical code of conduct (AAOGC, 2003).

The ethical code of conduct of the Hong Kong Institute of Certified Public Accountants (HKICPA) is an example of an accounting profession that follows the IFAC ethical code of conduct but with some modifications. Table 1 highlights the similarities and differences between the HKICPA and the IFAC ethical codes of conduct (HKICPA, 2010). The ethical codes of conduct of the Malaysian Institute for Accountants (MIA) and the Institute of Chartered Accountants in England and Wales (ICAEW) have also adopted the IFAC ethical code of conduct (ICAEW, 2006; MIA, 2010).

\section{Summary}

Based on the above discussion, Table 2 summarizes the main similarities and differences between the ethical codes of conduct of AICPA and IFAC. 
Table 2

General Comparison between the AICPA and IFAC Codes

\begin{tabular}{|c|c|c|}
\hline Issue & IFAC ethical code of conduct & $\begin{array}{l}\text { AICPA ethical code of } \\
\text { conduct }\end{array}$ \\
\hline $\begin{array}{l}\text { Establishment } \\
\text { Year }\end{array}$ & 1977 & 1887 \\
\hline Scope & International & $\begin{array}{l}\text { Specifically for the United } \\
\text { States of America }\end{array}$ \\
\hline $\begin{array}{l}\text { Employment with } \\
\text { an attest client }\end{array}$ & $\begin{array}{l}\text { Under certain circumstances, } \\
\text { firms may temporarily lend staff } \\
\text { to an audit client. }\end{array}$ & $\begin{array}{l}\text { Staff may not work under the } \\
\text { supervision of the attest client, } \\
\text { even temporarily. }\end{array}$ \\
\hline Structure & $\begin{array}{l}\text { The code consists of three } \\
\text { parts, i.e. A, B, and C. Part A } \\
\text { establishes the fundamental } \\
\text { principles of professional ethics } \\
\text { and provides a conceptual } \\
\text { framework for complying with } \\
\text { those principles. Parts B and C } \\
\text { describe how the conceptual } \\
\text { framework should be applied in } \\
\text { specific circumstances. }\end{array}$ & $\begin{array}{l}\text { The code consists of two } \\
\text { sections, i.e. the principles } \\
\text { and the rules. While the } \\
\text { principles provide the } \\
\text { framework for the ethical } \\
\text { values that professional } \\
\text { accountants should have, the } \\
\text { rules govern the performance } \\
\text { of professional services by } \\
\text { professional accountants. }\end{array}$ \\
\hline Approach & $\begin{array}{l}\text { The code is mainly a principle- } \\
\text { based code, which requires } \\
\text { professional accountants to } \\
\text { apply the conceptual framework } \\
\text { in all instances, i.e. conflicts of } \\
\text { interests, gifts and hospitality, } \\
\text { audit partner rotation, and fees } \\
\text { relative size. }\end{array}$ & $\begin{array}{l}\text { The code is mainly a rules- } \\
\text { based code. In the absence of } \\
\text { a specific rule, professional } \\
\text { accountants are encouraged } \\
\text { to apply the conceptual } \\
\text { framework approach.. }\end{array}$ \\
\hline $\begin{array}{l}\text { Independence } \\
\text { rules }\end{array}$ & $\begin{array}{l}\text { The rules of independence } \\
\text { include two parts, i.e. the } \\
\text { first part applies to financial } \\
\text { statement audits and reviews } \\
\text { and the second part addresses } \\
\text { all other assurance such as } \\
\text { attest services. The second part } \\
\text { is generally less strict than the } \\
\text { first part because it does not } \\
\text { impose prohibitions or other } \\
\text { requirements on public interest } \\
\text { entities. }\end{array}$ & $\begin{array}{l}\text { The rules of independence } \\
\text { applies to all attest services } \\
\text { except one case which } \\
\text { provides modified rules for a } \\
\text { narrow group of engagements } \\
\text { to issue restricted use reports. }\end{array}$ \\
\hline
\end{tabular}

(continued) 


\begin{tabular}{lll}
\hline \multicolumn{1}{c}{ Issue } & \multicolumn{1}{c}{ IFAC ethical code of conduct } & \multicolumn{1}{c}{$\begin{array}{c}\text { AICPA ethical code of } \\
\text { conduct }\end{array}$} \\
\hline $\begin{array}{l}\text { Public interest } \\
\text { entities* }\end{array}$ & $\begin{array}{l}\text { Imposes additional requirements } \\
\text { (including prohibitions) for } \\
\text { maintaining independence of } \\
\text { public interest entities, i.e. audit } \\
\text { partner rotation, significant } \\
\text { client fees, and certain non-audit } \\
\text { services. }\end{array}$ & $\begin{array}{l}\text { Does not include specific } \\
\text { requirements for public } \\
\text { interest entities although the } \\
\text { conceptual framework advises } \\
\text { members to consider whether } \\
\text { an entity is a public interest } \\
\text { entity. }\end{array}$ \\
\hline
\end{tabular}

*The AICPA's proposed definition of public interest entities is consistent with the IFAC definition and captures all listed entities and other entities for which the audit is required by law.

\section{Conclusion}

The main two accounting organizations, that have high influence internationally are the American Institute of Certified Public Accountants (AICPA) and the International Federation of Accountants (IFAC). While IFAC was founded to be an International umbrella for all accountants around the world, AICPA was founded specifically for the American accountants even though several accounting organizations in the world have adopted the AICPA ethical code of conduct. This could be because AICPA established the first major ethical code of conduct for the accounting profession in the 1890s. The main reason for developing the ethical code of conduct, for both AICPA and IFAC, is to guide accountants on how to react and response to any ethical dilemma. The requirements for accountants in business, for both AICPA and IFAC, are almost the same despite the fact that specific IFAC rules are more comprehensive than AICPA's, specifically in the issues of incentives and acting with adequate expertise. While some countries such as Taiwan, the Gulf Arab countries, and Jordan have adopted the AICPA ethical code of conduct, other countries such as Malaysia, England, and Hong Kong have adopted the IFAC ethical code of conduct.

In terms of approach, IFAC used the principles-based approach which was used to evaluate ethical behavior. In contrast, AICPA used the rules-based approach which required accountants to use the IFAC approach (i.e. principles-based) if the rules do not address their situation.

As for the principles of public interest and independence, the IFAC code consists of additional rules that reflect the public interest in 
certain types of entities such as entities whose securities are listed on recognized stock exchanges, and entities whose auditors are required by law or regulation to comply with the same independence requirements as listed entities. In contrast, the AICPA code does not include the previous mentioned entities. On the other hand, both codes divide independence into two types; independence of mind and independence in appearance. Even though the IFAC code explains the rules of independence in more detail than the rules of the AICPA code, both codes' rules of independence are composed of the same conceptual framework. The same independence' threats and safeguards are covered by AICPA and IFAC with minor differences in wording.

\section{References}

AAOGC. (2003). Code of ethics for professional accountants. Kingdom of Saudi Arabia, Riyadh: Accounting and auditing organization for gulf countries. Retrieved 15 October 2010, from www. gccaao.org

Abo-ahmeed, W. (2006).The extent of the auditor's compliance in Jordan with the ethical codes of professional conduct. Journal of University of the King Abduallah Abdalaziz, 20(2), 161-207.

AICPA. (2014). Code of ethics for professional accountants. USA: American Institute of Certified Public Accountants. Retrieved from www. aicpa.org

Ahmad, M. (2008). Code of ethics for professional accountants. Bangladesh, Dhaka: The Institute of Chartered Accountants of Bangladesh.

Allen, C. (2010). Comparing the ethics codes: AICPA and IFAC. USA: American Institute of Certified Public Accountants. Retrieved from http://www.journalofaccountancy.com/ Issues/2010/Oct/ 20103002

Bay, D. (1997). Determinants of ethical behavior: An experiment (Unpublished doctoral thesis). USA: Washington State University.

Brecht, H. (1991). Accountants' duty to the public for audit negligence: Self-regulation and legal liability. USA, Florida: University of Florida.

Brooks, L., \& Labelle, R. (2006). CAP forum on forensic accounting in the post-Enron world education for investigative and forensic accounting/formation ET Juricoptabilite. Canadian Accounting Perspectives, 5(2), 287-306. 
Brown, P. (1999). The AICPA code of professional conduct and exemplification: An empirical investigation of auditor and public perceptions (Unpublished doctoral thesis). USA: University of Mississippi.

Brown, P., Stocks, M., \& Wilder, W. (2007). Ethical exemplification and the AICPA code of professional conduct: An empirical investigation of auditor and public perceptions. Journal of Business Ethics, 71(1), 39-71.

Delorme, D., Sinkhan, G., \& French, W. (2001). Ethics and the internet issues associated with qualitative research. Journal of Business Ethics, 33(4), 271-286.

Duska, R., \& Duska, B. (2003). Accounting ethics (1st ed.). New York: Wiley-Blackwell.

ICAEW.(2006). Code of ethics for professional accountants for ICAEW. United Kingdom, London: Institute of Chartered Accountants in England and Wales. Retrieved from www.icaew.org

ICAO. (2010). ICAO rules of professional conduct. Canada, Ontario: Institute of Certified Accountants of Ontario. Retrieved from www.icao.org

IFAC. (2014). Code of ethics for professional accountants. USA: International Federation of Accountants. Retrieved from www. ifac.org

Garrison, R., \& Noreen, E. (1997). Managerial accounting (8th ed.). New York: McGraw-Hill.

Goldman, A., \& Barlev, B. (1974). The auditor-firm conflict of interests: Its implications for independence. Accounting Review, 49(4), 707-718.

HKICPA.(2010). Code of ethics for professional accountants for HKICPA. China, Hong Kong: Hong Kong Institute of Certified Public Accountants. Retrieved from www.hkicpa.org.hk

Mele, D. (2005). Ethical education in accounting: Integrating rules, values and virtues. Journal of Business Ethics, 57(1), 97-109.

MIA. (2010). Code of ethics for professional accountants for MIA. Malaysia, Kuala Lumpur: Malaysian Institute for Accountants. Retrieved from www.mia.org

Parker, L. (1994). Professional accounting body ethics: In search of the private interest. Accounting, Organizations and Society, 19(6), 507-525.

Payne, D., \& Landry, B. (2005). Similarities in business and IT professional ethics: The need for and development of a comprehensive code of ethics. Journal of Business Ethics, 62(1), 73-85. 
Rezaee, Z., Elmore, R., \& Szendi, J. (2001). Ethical behavior in higher educational institutions: The role of the code of conduct. Journal of Business Ethics, 30(2), 171-183.

SOCPA. (2009). Code of ethics for professional accountants. Kingdom of Saudi Arabia, Riyadh: Saudi Organization for Certified Public Accountants. Retrieved from www.socpa.org

Venezia, C. (2005). The ethical reasoning abilities of accounting students. The Journal of American Academy of Business, 6(1), 200-207.

Windsor, C., \& Ashkanasy, N. (1995). The effect of client management bargaining power, moral reasoning development, and belief in a just world on auditor independence. Accounting, Organizations and Society, 20(7), 701-720.

Wotruba, T., Chonko, L., \& Loe, T. (2001). The impact of ethics code familiarity on manager behavior. Journal of Business Ethics, 33(1), 59-69. 